\title{
脳動静脈奇形摘出術中の脳皮質血流量測定
}

\author{
田中柳水宮坂佳男常盤嘉一
}

\section{Changes in the Cortical Blood Flow \\ after the Surgical Removal of an Arteriovenous Malformation}

by

\author{
Ryusui Tanaka, M.D., Yoshio Miyasaka, M.D., Kaichi Tokiwa, M.D., \\ from
}

Department of Neurosurgery, Kitasato University School of Medicine

Just before and after the surgical removal of an arteriovenous malformation (AVM), the authors intraoperatively measured the local blood flow in the cortex (LCoBF) surrounding an AVM in 24 cases (16 superficial, 8 deep AVMs), and have studied the relationship between these two time-point values and the subsequent hemodynamic complications, i. e., breakthrough swelling and/or breakthrough hemorrhaging.

All LC.oBFs were determined by employing a thermal diffusion probe that uses a Pertier stack. In all cases, assessment of the postoperative complications was made by CT, and in 12 of the 24 cases, the intracranial pressure (ICP) was also measured.

After the removal of the AVM, an LCoBF increase was seen in 11 cases, an LCoBF decrease in 7 cases, and no change in 6 cases. In all 11 patients with the blood flow increase, the AVM had been superficially situated, whereas cases showing a blood flow decrease or no blood flow change had deep AVMs. As for AVM size and its relationship to the LCoBF changes after AVM removal, an LCoBF increase was observed in 5 of 12 cases with a large AVM, and in 6 of 12 cases with a small AVM.

With regard to the relationship between the postoperative ICP and the LCoBF change after the AVM removal, in one case only, the ICP rose of above $25 \mathrm{mmHg}$ on the third day. Postoperative CTs were used to evaluate all cases treated, and only in this case that showed an ICP above $25 \mathrm{mmHg}$ was postoperative hemorrhaging seen.

Attention has gradually focused on the breakthrough of the normal perfusion pressure as being the cause of hemorrhagic complications after the surgical removal of an AVM, though such complications appear to arise from more causes than had been previously thought. The results of our study would seem to indicate that the postoperative intracranial blood flow around the site of a resected AVM has no direct bearing on postoperative hemorrhag. ing and/or brain swelling. In cases where hemorrhaging occurs after the AVM has been removed, careful consideration should be given to other possible causes like disorders in the venous blood flow and/or hemodynamic complications in the arteries, such as an insecure hemostasis with a high pressure afterload.

(Received March 51992 ; accepted May 11, 1992)

\footnotetext{
Key words : arteriovenous malformation, local cortical blood flow (LCoBF), intraoperative monitoring, hemodynamic complication
}

Jpn J Neurosurg (Tokyo) 1:256-259, 1992 


\section{はじめに}

脳動静脈奇形 $(\mathrm{AVM})$ 摘出後の AVM 周囲の脳血液 循環動態を理解することは治療上きわめて重要であると 思われる. AVM 摘出後の問題としては, normal perfusion pressure breakthrough (NPPB) による術後の 出血が強調されている。われわれは AVM 摘出術におい て AVM 周囲の術中皮質血流量 (LCoBF) を測定し， AVM 摘出術前後の LCoBF 変化と hemodynamic complication (breakthrough hemorrhage, breakthrough swelling）との関連性について検討したので報告する。

\section{対象と方法}

摘出術中 AVM 周囲の $\mathrm{LCoBF}$ を測定した 24 例を対 象とした。 LCoBF の測定は Pertier stack を用いた熱 勾配式組織血流量測定装置 (BTG III, バイオメヂカルサ イエンス社製）を使用した。測定部位は術中開頭部にお いて nidus より $2 \mathrm{~cm}$ 以上離れた脳表で, 太い血管にプ レート型プローベが当たらないよう考慮し密着させた。 また, AVM 摘出前, 後でほぼ同一部位の $\mathrm{LCoBF}$ が測 定できるように配慮した。全例手術中に持続的体血圧の 測定と適時 $\mathrm{PaCO}_{2}$ の測定を行った。 $\mathrm{LCoBF}$ 測定時の平 均体血圧は摘出前值が $126.3 \pm 20.1 / 67.1 \pm 13.2 \mathrm{mmHg}$, 摘出後值が $125.8 \pm 22.0 / 66.3 \pm 14.2 \mathrm{mmHg}$ ，また $\mathrm{PaCO}_{2}$ は前值が $33.47 \pm 3.38 \mathrm{mmHg}$, 後値が $33.93 \pm 3.88 \mathrm{~mm} \mathrm{Hg}$ であり，有意差は認めなかった。術後の hemodynamic complication の判定は全例術後の CT で行い, 24 例中 12 例では術後頭蓋内压 (ICP) 測定も行った。

\section{結 果}

\section{1] AVM 摘出前後の LCOBF 变化率}

$\mathrm{LCoBF}$ 変化率 (\% changes in the $\mathrm{LCoBF}$ after AVM removal) は,

$$
\underset{(\%)}{\mathrm{LCoBF}} \text { 変化率 }=\frac{\text { postoperative value }- \text { preoperative value }}{\text { preoperative value }} \times 100
$$

として計算した。 LCoBF 変化率がいくらかでも増加を 示した症例は 11 例であり, 変化率は+ $3 \sim+160 \%$ で あった。 LCoBF 変化率がいくらかでも減少を示したの は7例であり，変化率はー3〜-44\%であった。残りの 6 例は変化率は 0 であった。 Fig. 1 は, AVM 摘出前後 の LCoBF 変化率と AVM の局在の関係について検討 したものである。対象としたAVM を表在性 16 例，深

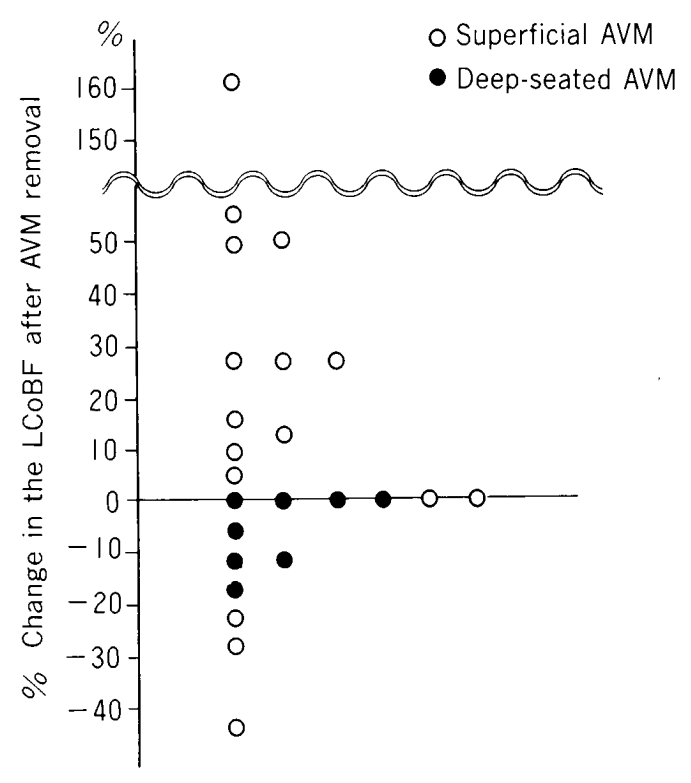

Fig. 1 Postoperative changes in the LCoBF in relation to localization of the AVM

Table 1 Relationship between AVM size and LCoBF

\begin{tabular}{l|c|c}
\hline \multirow{2}{*}{ LCoBF } & \multicolumn{2}{c}{ AVM size } \\
\cline { 2 - 3 } & $<4 \mathrm{~cm}$ & $\geqq 4 \mathrm{~cm}$ \\
\hline Increased & 5 cases & 6 cases \\
No change or a decrease & 7 cases & 6 cases \\
\hline
\end{tabular}

LCoBF : local cortical blood flow

在性 8 例に分類し検討してみると, 摘出後に血流量が増 加した 11 例はすべて表在性 AVM であった。一方, 深 在性 AVM 8 例すべては摘出後の血流量が不変か, 減少 した症例であった。

\section{2] AVM の大きさと AVM 摘出前後の LCOBF 变化率}

Yasargil ら ${ }^{10)} の$ 定義に従い, AVM の最大径が $4 \mathrm{~cm}$ 以上の large AVM と $4 \mathrm{~cm}$ 未満の small AVM に分け て LCoBF 変化率との関係を検討した結果が Table 1 で ある. $\mathrm{LCoBF}$ 変化率の増加を認めた症例は, large AVM が $5 / 12$ 症例, small AVM が $6 / 12$ 症例であり, 両者に 有意差はなかった。また，表在性 AVM 16 例にだけかぎ り検討した結果でも, LCoBF 変化率の増加を認めた症 例は, large AVM が $6 / 8$ 症例, small AVM が $5 / 8$ 症 例であり，両者に有意差は認めなかった。

\section{3 術後 ICP と AVM 摘出前後の LCOBF 变化率}

Fig. 2 は, 術後にICPを測定した 12 例について 


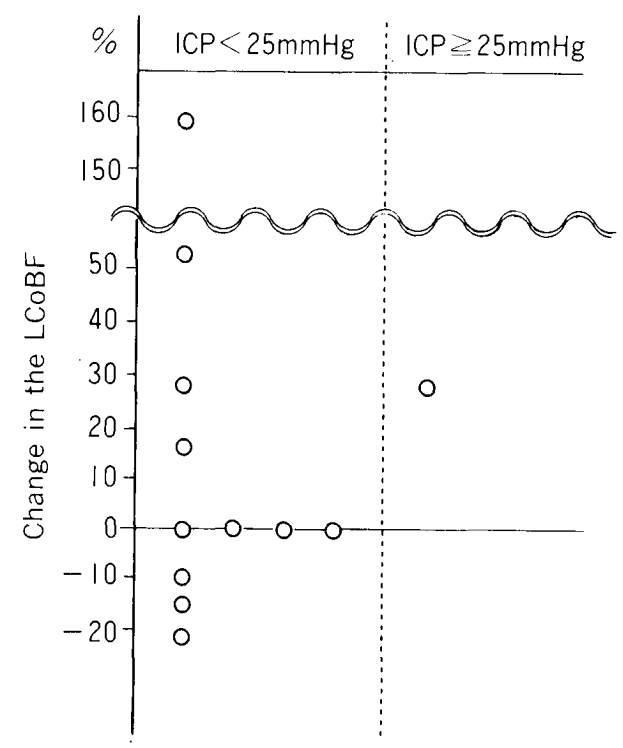

Fig. 2 Relationship between the postoperative ICP and the LCoBF

Table 2 Relationship between the postoperative course and the LCoBF

\begin{tabular}{c|c|c}
\hline \multirow{2}{*}{ LCoBF } & \multicolumn{2}{|l}{$\begin{array}{l}\text { Postoperative hemorrhaging and/ } \\
\text { or brain swelling assessed by CT. } \\
\text { Also by ICP recording with neuro- } \\
\text { logical deficits }\end{array}$} \\
\cline { 2 - 3 } & $(+)$ & $(-)$ \\
\hline $\begin{array}{c}\text { Increased }(\mathrm{N}=11) \\
\text { No change or a } \\
\text { decrease } \\
(\mathrm{N}=13)\end{array}$ & 1 & 10 \\
\hline Total & 0 & 13 \\
\hline
\end{tabular}

LCoBF : local cortical blood flow:

$\mathrm{LCoBF}$ 変化率と術後 ICPとの関係を示している。 LCoBF 梁化率が $50 \%$ ，160\%とかなり上昇した症例で も, 術後のICPは25 mmHg 未満で安定していた。 $\mathrm{LCoBF}$ 変化率が $27 \%$ に增加した1例のみが, 術後3日 目にICP が $25 \mathrm{mmHg}$ 以上に上帠した。対象としたす べての註例について術後にCT が施䘕されているが, 術

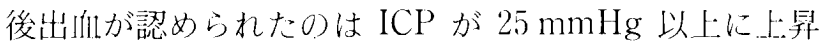
したこの1症例のみであった。この症例の出血について は hemorrhagic venous infarction が原因であるとすで に報告している゙，それ以外の症例に扔いても術後に hemodynamic complication が問題となった症例は認め なかった (Table 2).

\section{考按}

AVM 摘出前後の脳出血, 脳腄脤の原因として, (1) AVM 0 )残存 ${ }^{61101}$, (2) NPPB ${ }^{81}$, (3) insecure hemostasis with a high pressure afterload ${ }^{31}$, (4) overload

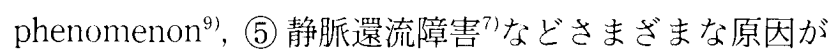
考えられている.特に, Spetzler が提唱した NPPB が 出血の原因として注目されている. AVM 周囲の慢性的 な乏血状態に曝された脳組織は autoregulationを失っ て抢り，このような脳組織に AVM 摘出前後, 急激に脳 血流量が増加するために出血または脳腫脹をきたすとい うのが NPPB の概念である。しかし，NPPB に関して は，その存在を疑問視する報告もある ${ }^{10)}$. したがって， AVM の摘出術中に実際に脳血流を測定することによっ て，このような概念と術中，術後の脳腫脹，脳出血との 関連性を検討する必要がある ${ }^{155}$. Peltier stack を用いた 脳皮質血流測定は測定範囲は制限されるものの，リアル タイムに血流量が示されるために, 術中の LCoBF の変 動をみるためのモ二ターとしてその有用性は大きい22.

この Peltier stack を用いた今回の検討では, AVM 摘 出後 $\mathrm{LCoBF}$ の増加例と, 不変例㧍よび減少例がみられ た。摘出後 $\mathrm{LCoBF}$ の堌加する症例は, 表在性 AVM で は 16 例中 11 例と高頻度であったＡVMによってシャ ントされていた血流が摘出後, 周囲の脳組織に還流する ために AVM のみならず，正常脳へも血液供給を行う， いわゆる transit feeder を術中に犠牲にしなければ，こ れら表在性 AVM 摘出後に皮質血流が增加することは 当然考えられる現象である. 今回の検討では, $\mathrm{LCoBF}$ の 增加は従来から NPPB をきたしやすいとされる大きな AVM に限定した現象ではなく, $4 \mathrm{~cm}$ 末満の AVM に

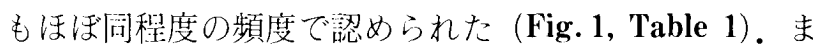
た, 術後 ICP 測定, 画像所見から判定した脳腫脹, 脳出 血と術中の $\mathrm{LCoBF}$ の増加との間にも有意な関連性は得 られなかった (Fig. 2, Table 2). すなおち摘出後, $50 \%$ ， $160 \%$ LCoBF の上帠率が高かった 2 例も，出血性の会 併症や脳腫脹はなかった。唯一の脳出血例は LCoBF 增 加率が $27 \%$ 示し, AVM 摘出 3 日後に出向し, 静脈還 流障害として報告した 1 例のみであっだ、すなおち，今 回の検討では表在性 AVM の摘出後の周囲脳の LCoBF の増加はしばしばみられる現象であり，AVM 摘出後の 脳血流晴增加が直ちに術後出血, 脳腫脹に直結するとい う結果は得られなかった。

今後, 動脈系の血行力学的合併症を論ずるには $\mathrm{LCoBF}$ の上昇に加えて, 摘出後の流入動脈圧の上昇率 などを加味して，畣併症を予測し対処すること"が大切 であろう。術後の出血性の合併症の原因として NPPB が中心的な考えになりつつあるが，その原因は従来考え られていたよりも多彩である。基本的にはまず残存 AVM を除外 ${ }^{6)}$, さらに insecure hemostasis with a 
high pressure afterload ${ }^{3)}$ など動脈系の血行力学的合併 症に加えて, 静脈系の還流障害》も十分に考慮すべきで ある。なお, $\mathrm{LCoBF}$ 不変または減少例の多くは深在性の AVM であり，本方法による血流測定が深部の血流動態 を反映しない可能性と, 深部の AVM 摘出時の脳圧排に よる血流減少を反映している可能性が考えられる.

\section{文 献}

1) Barnett GH, Little JR, Ebrahim ZY, Jones SC, Friel HT : Cerebral circulation during arteriovenous malformation operation. Neurosurgery 20:836-842, 1987.

2) Carter LP, Erspamer R, Bro WJ : Cortical blood flow : thermal diffusion vs isotope clearance. Stroke $12: 513-518,1981$.

3) Drake CG, Friedman AH, Peerless SJ : Posterior fossa arteriovenous malformation. J Neurosurg 64 : $1-10,1986$

4）端 和夫：Large AVM の手術の問題点. 脳血管外科の フロンティア. 第 6 回 The Mt. Fuji Workshop on CVD

\section{$6: 193-203,1988$}

5) Leblanc R, Little JR: Hemodynamics of arteriovenous malformations. Clin Neurosurg $36: 299$ $-317,1988$.

6）宮坂佳男, 田中柳水, 田中千彦, 常盤嘉一, 北原行雄, 入倉克巳, 倉田 彰, 斎藤元良, 遠藤昌孝, 中山賢司, 森井誠二, 矢田賢三, 北原孝雄, 大和田隆：大型 AVM の手術成績に関連する諸因子と対策。脳卒中の外科 $18: 215-256,1990$.

7) Miyasaka Y, Yada K, Ohwada T, Kurata A, Tokiwa K, Suwa T, Yamada M, Oka H : Hemorrhagic venous infarction after excision of an arteriovenous malformation: Case report. Neurosurgery 29:265-268, 1991.

8) Spetzler RF, Wilson CB, Weinstein P : Normal perfusion pressure breakthrough theory. Clin Neurosurg $25: 651-672,1978$.

9）杉田虔一郎，竹前紀樹：Large AVM の手術. Neurosurgeons $7: 35-41,1988$.

10) Yasargil MG: Microneurosurgery III A. Stuttgart, New York, Georg Thieme Verlag, Thieme Medial Publishers Inc, 1987, pp. 85-138, pp. 213-239.

\section{脳動静脈奇形摘出術中の脳皮質血流量}

巴中柳水宮坂 佳男常盤 嘉一

Arteriovenous malformation (AVM) 摘出術後の出血性の合併症の原因として, normal perfusion pressure breakthrough (NPPB) ガ中心的な考えになりつつあるが, その原 因は従来考えられているよりも多彩である. そこでわれわれは, AVM 摘出術において AVM 周囲 の術中皮質血流量 (LCOBF) を測定し, AVM 摘出術前後の LCOBF 变化と hemodynamic complication (breakthrough hemorrhage, breakthrough swelling). との関連性に ついて検討した．今回のわれわれの検討では，AVM 摘出後の AVM 周囲の脳血流量増加が直ちに 術後出血, 脳腫脹に直結するという結果は得られなかつた。 